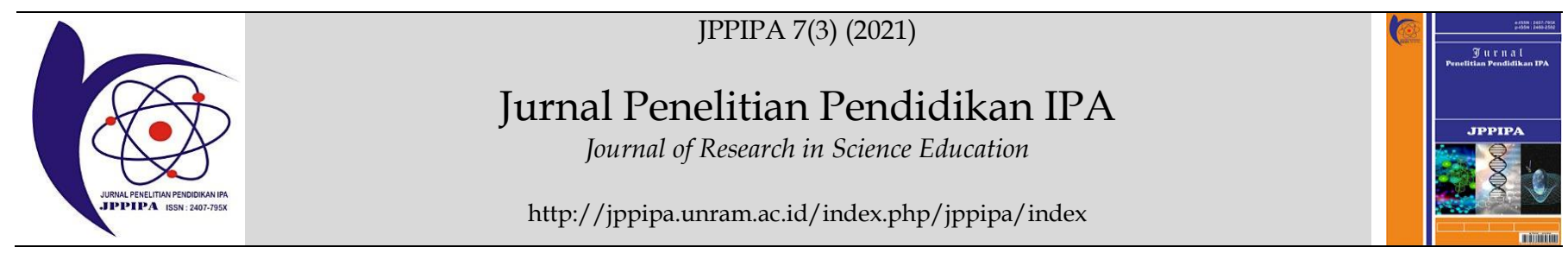

\title{
Online Learning During the Covid-19 Pandemic: Preservice Teacher's Perception
}

\author{
Agus Muliadi ${ }^{1}$, Saiful Prayogi², Farida Bahalwan ${ }^{3}$, Wa Nirmala4 ${ }^{4}$ \& Ni Nyoman Sri Putu Verawati ${ }^{*}$ \\ ${ }^{1}$ Department of Biology Education, Universitas Pendidikan Mandalika, Mataram, West Nusatenggara, Lombok, Indonesia. \\ ${ }^{2}$ Department of Physic Education, Universitas Pendidikan Mandalika, Mataram, West Nusatenggara, Lombok, Indonesia. \\ ${ }^{3}$ Department of Biology Education, Universitas Darussalam Ambon, Maluku, Indonesia. \\ ${ }^{4}$ Department of Chemistry Education, Universitas Darussalam Ambon, Maluku Indonesia. \\ ${ }^{5}$ Department of Physic Education, University of Mataram, Mataram, West Nusatenggara, Lombok, Indonesia.
}

DOI: $\underline{10.29303 / \text { ippipa.v7i3.787 }}$

\section{Article Info}

Received: June $8^{\text {th }}, 2021$

Revised: July 10th 2021

Accepted: July 14th 2021

\begin{abstract}
This study aims to explore preservice teacher's perception of online learning during the Covid-19 pandemic. This study is a descriptive-exploratory research where respondents are 107 preservice teachers from four study programs that provide preservice teacher's education, namely Mathematics Education, Biology Education, Physics Education, and Chemistry Education in the Mandalika University of Education-Indonesia. An instrument in the form of a questionnaire was used with a Likert scale and has been validated (expert validation). The research data were analyzed descriptively and statistically using the analysis of variance (ANOVA) test. The study results show that the preservice teacher's perception of online learning modes during the Covid-19 pandemic is "quite" category, and there is no significant difference in preservice teachers' perceptions of online learning during the Covid-19 pandemic. Descriptions of the results of further studies are presented in this article.
\end{abstract}

Keywords: online learning; Covid-19 pandemic; preservice teacher's perception

Citation: $\quad$ Muliadi, A., Prayogi, S., Bahalwan, F., Nirmala, W., \& Verawati, N. (2021). Online Learning During the Covid-19 Pandemic: Preservice Teacher's Perception. Jurnal Penelitian Pendidikan IPA, 7(3), 464-467. doi:https://doi.org/10.29303/jppipa.v7i3.787

\section{Introduction}

The corona virus diseases 2019 (Covid-19) pandemic has hit 215 countries in the world, including Indonesia. The Covid-19 pandemic in Indonesia has an impact on all aspects of social and economic life, including education. To avoid the spread of the Covid19 pandemic, the central and regional governments made policies related to social and physical distancing, wearing masks, and always washing hands (Gultom \& Sitanggang, 2020; Sadikin \& Hamidah, 2020). As the number of positive Covid-19 patients in Indonesia continues to increase, the government, through the Ministry of Education, has implemented a learning from home (LFH) program for all levels of education, including higher education. Universities in Indonesia are required to be able to organize online learning (Firman \& Rahayu, 2020) by utilizing internet media. Referring to this policy, the Mandalika University of Education as the provider of higher education, eliminates conventional lectures (face-to-face) and replaces them with online learning systems utilizing internet technology and media synchronously or asynchronously.

Online learning is learning that uses internet networks with accessibility, connectivity, flexibility, and the ability to generate various types of learning interactions (Maulah et al., 2020; Pangondian et al., 2019). Previous studies have shown that the use of the internet and multimedia technology is able to change the way knowledge is transferred and can be an alternative to learning carried out in traditional 
classrooms (Sadikin \& Hamidah, 2020). Online learning is learning that is able to bring together students and lecturers to carry out learning interactions with the help of the internet (Kuntarto, 2017). Online learning is expected to be a momentum to develop innovative technology-based learning effectively to replace learning with face-to-face learning in class (Saifuddin, 2017). In conventional learning, so far, students tend to be only reactive to their environmental conditions but do not play an active role in their environment (Yuniarti, 2010). Online learning can increase the role of students in the learning process. Online learning services are available both independently managed by institutions with a Learning Management System (LMS) and other parties such as social media platforms. The use of online learning can increase interactivity and learning efficiency because it gives students a higher potential to communicate more with lecturers, colleagues and access more learning materials (Zhafira et al., 2020).

In Indonesia, the internet and online media have been massively used by all circles of society, but their use as learning media is relatively new and was applied when the Covid-19 pandemic hit Indonesia. This study explores the pre-service teacher's perception at the Mandalika University of Education on online learning during the Covid-19 pandemic. The online learning model implemented at the Mandalika University of Education is LMS using Moodle version 4.0, zoom meetings, google classroom, and WhatsApp groups.

\section{Method}

This study is descriptive-exploratory research where respondents are 107 preservice teachers from four study programs that provide preservice teacher's education at the Mandalika University of Education Indonesia. The distribution of respondents are 27 from mathematics education, 38 from biology education, 19 from chemistry education, and 23 from physics education. The instrument used is a "closed questionnaire" with degraded answer choices based on the Likert scale (Muliadi, 2020a). The questionnaire on student-teacher student perceptions of online learning used in this study was prepared to refer to the perception indicator learning interactions, learning process management, learning evaluation, and learning environment (Adijaya \& Santosa, 2018). This indicator is developed into 15 statements and validated by experts, and declared valid.

The research data analysis was conducted using descriptive and inferential statistics. Descriptive analysis was used to describe preservice teacher's perceptions of online learning during the Covid-19 pandemic. Perceptual mean $(\bar{p})$ converted into categories; very good (3.51-4.00), good (2.51-3.50), quite $(1.51-2.50)$, and less (1.00 - 1.50) (Muliadi, 2020b). Inferential statistics are used to determine differences in the perceptions of student-teacher candidates for each study program. The analysis technique used is the Anova (analysis of variance) test at the 0.05 significance level, with the statistical hypothesis formulation, namely $\mathrm{H}_{0}: \mu_{1}=\mu_{2}$ (there is no significant difference in the perceptions of preservice teachers between study programs of online learning during the Covid-19 pandemic) and $\mathrm{H}_{1}: \mu_{1} \neq \mu_{2}$ (there is a significant difference in preservice teacher's perceptions of online learning during the Covid-19 pandemic). If the results of the analysis are significant or the p-value of the correlation test is smaller than 0.05 , then $\mathrm{H}_{0}$ is rejected and $\mathrm{H}_{1}$ is accepted or otherwise. If the Anova test results are significant, then a further test is carried out using the Tukey HSD test.

\section{Result and Discussion}

The data description of the results of measuring preservice teacher's perceptions of online learning during the Covid-19 pandemic is presented in Table 1.

Table 1. Preservice teacher's perceptions

\begin{tabular}{|c|c|c|c|c|c|}
\hline No & $\begin{array}{l}\text { Study Programs/ } \\
\text { Department }\end{array}$ & $\mathrm{n}$ & $\Sigma$ Score & Average & Category \\
\hline 1 & $\begin{array}{l}\text { Mathematics } \\
\text { education }\end{array}$ & 27 & 65.00 & 2.42 & quite \\
\hline 2 & Biology education & 38 & 86.64 & 2.28 & quite \\
\hline 3 & $\begin{array}{l}\text { Chemistry } \\
\text { education }\end{array}$ & 19 & 41.36 & 2.18 & quite \\
\hline 4 & Physics education & $\begin{array}{l}23 \\
107\end{array}$ & $\begin{array}{l}54.00 \\
247.00\end{array}$ & $\begin{array}{l}2.33 \\
2.30\end{array}$ & $\begin{array}{l}\text { quite } \\
\text { quite }\end{array}$ \\
\hline
\end{tabular}

The description of the measurement data in Table 1 shows the preservice teacher's perceptions of online learning during the Covid-19 pandemic on average in quite category $(\bar{p}=2.30)$.

The data of preservice teacher's perceptions of online learning during the Covid-19 pandemic were analyzed statistically, provided that the data variance was homogeneous and normally distributed. The results of the homogeneity test (Levene's test) and normality (Kolmogorov-Smirnov's test), respectively, are 0.889 and 0.909 , both of which are greater than alpha testing (>0.05), and it can be stated that the data variants are homogeneous and normally distributed. Furthermore, data on differences in perceptions of student teacher candidates for each study program were analyzed using the Anova test and further tests using the Tukey HSD test. The Anova test results are presented in Table 2. 
Tabel 2. The Anova test results

\begin{tabular}{lllllll}
\hline No & & $\begin{array}{l}\text { Sum of } \\
\text { Squares }\end{array}$ & df & $\begin{array}{l}\text { Mean } \\
\text { Square }\end{array}$ & F & Sig. \\
\hline 1 & $\begin{array}{l}\text { Between } \\
\text { Groups }\end{array}$ & 138.611 & 3 & 46.204 & 1.465 & 0.228 \\
2 & $\begin{array}{l}\text { Within } \\
\text { Groups }\end{array}$ & 3247.819 & 103 & 31.532 & & \\
3 & Total & 3386.430 & 106 & & & \\
\hline
\end{tabular}

The Anova test results show that the significance value of 0.228 is greater than the alpha testing alpha value $(>0.05)$. Therefore $\mathrm{H}_{1}$ is rejected, and $\mathrm{H}_{0}$ is accepted, which means that there is no significant difference in preservice teacher's perceptions of online learning during the Covid-19 pandemic.

The elaboration of the results of this study shows that online learning at the Mandalika University of Education was less effective during the Covid-19 pandemic. This is due to many factors, one of which is that the preparation for using online learning has not been maximal. The effectiveness of online learning must be supported by the readiness of lecturers, students, and the learning environment. This is in accordance with previous studies that online learning requires maximum effort and support from all parties, both educators and families. Educators and parents are required to create an integrated learning environment and fulfill various essential components of learning, namely discursive, adaptive, interactive, and reflective (Oktavian et al., 2020; Ulfah et al., 2020; Daheri et al., 2020; Sobron et al., 2019).

The online learning model implemented at the Mandalika University of Education provides four platform choices: learning management system (LMS) using Moodle version 4.0, zoom meetings, google classroom, and WhatsApp groups. However, in its implementation, lecturers use WhatsApp groups more widely used by lecturers as a choice of online learning media compared to the other three media. This has an impact on the lack of student interactivity and learning motivation because WhatsApp media does not allow video calls with all students at the same time so that two-way interaction is very limited in online learning between lecturers and students or between students.

Student response in this study revealed that online learning has limitations in the process of interaction, discussion, collaboration, feedback, and response. This condition makes students experience limitations in submitting income, questions, and problems faced in online learning, making miscommunication between lecturers and students or between students possible. This is in accordance with the argument of Sadikin \& Hamidah (2020) that online learning has special challenges. The location of separate students and lecturers when implementing it causes lecturers to not be able to interact, guide, and directly supervise student activities during the learning process. As a result, there is no guarantee that students really listen to the elaboration of material from the lecturer to miscommunication (Batubara \& Batubara, 2020). Students often fantasize when online learning is compared to face-to-face lectures (Szpunar et al., 2013).

Students admit online learning to be less effective in getting explanations and solving problems with lecture material from lecturers. This is because it is in accordance with the results of Sadikin \& Hamidah's (2020) research that not a few students have difficulty understanding the lecture material that is given online. Teaching materials and independent assignments are usually delivered in the form of reading that students as a whole do not easily understand. Students assume that independent materials and assignments are not sufficient because they need direct explanations by lecturers (Sadikin \& Hamidah, 2020; Oknisih \& Suyoto, 2019; Aina, 2016; Swan, 2002).

\section{Conclusion}

The results of the study show that the perceptions of prospective teachers at the Mandalika University of Education on online learning modes during the Covid-19 pandemic are quite category, and there is no significant difference in preservice teacher's perceptions of online learning during the Covid-19 pandemic. These findings can be used as a basis for institutions to provide optimal services to learners in online learning during the Covid-19 pandemic because the desired learning outcomes depend heavily on learning services provided by lecturers.

\section{Acknowledgments}

The researcher would like to thank the parties involved in this study, including the sponsors who funded the research process.

\section{References}

Aina, M. (2016). Pengembangan multimedia interaktif menggunakan camtasia studio 8 pada pembelajaran biologi materi Kultur Jaringan untuk siswa SMA kelas XI MIA. Jurnal Biodik, 2(1). Retrieved from: https://onlinejournal.unja.ac.id/biodik/article/view/3365 [Indonesian]

Batubara, H. H., \& Batubara, D. S. (2020). Penggunaan video tutorial untuk mendukung pembelajaran daring di masa pandemi virus Corona. Muallimuna: Jurnal Madrasah Ibtidaiyah, 5(2), 7484. 
http://dx.doi.org/10.31602/muallimuna.v5i2.29 50 [Indonesian]

Firman, F., \& Rahayu, S. (2020). Pembelajaran online di tengah pandemi Covid-19. Indonesian Journal of Educational Science (IJES), 2(2), 81-89. doi: https://doi.org/10.31605/ijes.v2i2.659 [Indonesian]

Gultom, C. R. \& Sitanggang, S. G. M. (2020). Persepsi mahasiswa Unika terhadap kuliah online di masa pandemi covid 19. Jurnal Pendidikan Bahasa Indonesia dan Sastra (PEDISTRA), 3(1), 6-15. doi: http://dx.doi.org/10.1234/pbis.v3i1.771 [Indonesian]

Kuntarto, E. (2017). Keefektifan model pembelajaran daring dalam perkuliahan Bahasa Indonesia di perguruan tinggi. Indonesian Language Education and Literature, 3(1), 99-110. doi: http://dx.doi.org/10.24235/ileal.v3i1.1820 [Indonesian]

Maulah, S., Nurul, F. \& Ummah, N.R. (2020). Persepsi mahasiswa biologi terhadap perkuliahan daring sebagai sarana pembelajaran selama pandemi Covid-19. ALVEOLI: Jurnal Pendidikan Biologi, 1(2), 49-61. Retrieved from: https://alveoli.iainjember.ac.id/index.php/alv/article/view/6 [Indonesian]

Muliadi, A. (2020). Sikap entrepreneur mahasiswa pendidikan biologi. Jurnal Ilmu Sosial dan Pendidikan, 4(3), 286-291. doi: http://dx.doi.org/10.36312/jisip.v4i3.1208 [Indonesian]

Muliadi, A. (2020). Perbedaan gender dalam sikap entrepreneur mahasiswa pendidikan biologi. Jurnal Ilmiah Mandala Education, 6(2), 329-334. doi: http://dx.doi.org/10.36312/jime.v6i2.1439 [Indonesian]

Oknisih, N., \& Suyoto, S. (2019). Penggunaan APLEN (aplikasi online) sebagai upaya kemandirian belajar siswa. Seminar Nasional Pendidikan Dasar, 1(1), 477-483 [Indonesian]

Oktavian, R., \& Aldya, R. F. (2020). Efektivitas pembelajaran daring terintegrasi di era pendidikan 4.0. Didaktis: Jurnal Pendidikan dan Ilmu Pengetahuan, 20(2), 129-135. doi: http://dx.doi.org/10.30651/didaktis.v20i2.4763 [Indonesian]

Pangondian, R. A., Santosa, P. I., \& Nugroho, E. (2019). Faktor-faktor yang mempengaruhi kesuksesan pembelajaran daring dalam revolusi industri 4.0. Seminar Nasional Teknologi Komputer \& Sains (SAINTEKS), 1(1), 56-60. Retrieved from: https://www.prosiding.seminarid.com/index.php/sainteks/article/view/122 [Indonesian]
Sadikin, A. \& Hamidah, A. (2020). Pembelajaran daring di tengah wabah Covid-19. BIODIK: Jurnal Ilmiah Pendidikan Biologi, 6(2), 214-224. doi: https://doi.org/10.22437/bio.v6i2.9759 [Indonesian]

Saifuddin, M.F. (2017). E-Learning dalam persepsi mahasiswa. Jurnal Varia Pendidikan, 29(2), 102109. [Indonesian]

Ulfah, Y., \& Suryantoro, A. (2020). Studi awal tentang penggunaan media daring selama pandemi Corona di SMPN Purworejo Lampung Tengah. Al Jahiz: Journal of Biology Education Research, 1(1), 34-43. Retrieved from: https://ejournal.metrouniv.ac.id/index.php/Al\ahiz/article/view/2046 [Indonesian]

Daheri, M., Juliana, D., \& Amda, A.D. (2020). Efektivitas whatsapp sebagai media belajar daring. Jurnal Basicedu, 4(4), 775-783. doi: https://doi.org/10.31004/basicedu.v4i4.445 [Indonesian]

Sobron, A. N., \& Bayu, R. (2019). Persepsi siswa dalam studi pengaruh daring learning terhadap minat belajar IPA. SCAFFOLDING: Jurnal Pendidikan Islam dan Multikulturalisme, 1(2), 30-38. doi: https://doi.org/10.37680/scaffolding.v1i2.117 [Indonesian]

Szpunar, K. K., Moulton, S. T., \& Schacter, D. L. (2013). Mind wandering and education: From the classroom to online learning. Frontiers in Psychology, 4, 1-7. doi: https:/ / dx.doi.org/10.3389\%2Ffpsyg.2013.00495

Swan, K. (2002). Building learning communities in online courses: The importance of interaction. Education, Communication \& Information, 2(1), 2349. doi: https://doi.org/10.1080/1463631022000005016

Yuniarti, R.D. (2010). Potensi E-Learning melalui sistem kuliah on-line dalam meningkatkan kualitas pembelajaran di prodi tata niaga jurusan pendidikan ekonomi FPEB-UPI. Jurnal ANAJERIAL, 8(16), 66-77. doi: https://doi.org/10.17509/manajerial.v9i1.1215 [Indonesian]

Zhafira, N.H., Ertika, Y. \& Chairiyaton. (2020). Persepsi mahasiswa terhadap perkuliahan daring sebagai sarana pembelajaran selama masa karantina Covid-19. Jurnal Bisnis dan Kajian Strategi Manajemen, 4(1), 37-45. doi: https://doi.org/10.35308/jbkan.v4i1.1981 [Indonesian] 